Серія: Педагогічні науки. - Вип.3. - Бердянськ : БДПУ, 2019. - 453 с.

УДК 373.5.016:53

DOI 10.31494/2412-9208-2019-1-3-120-127

\title{
PHYSICAL AND TECHNICAL MODELING IN FORMING PRACTICAL-ORIENTED KNOWLEDGE
}

\section{ФІЗИКО-ТЕХНІЧНЕ МОДЕЛЮВАННЯ У ФОРМУВННІ ПРАКТИКО-ОРІЕНТОВАНИХ ЗНАНЬ}

\author{
Ivan KOSOGOV, \\ Postgraduate Student \\ Іван КОСОГОВ, \\ аспірант \\ ivankosogov64@gmail.com \\ Berdiansk State Pedagogical \\ Бердянський державний \\ University, \\ $\triangle 4$ Schmidta St., \\ Berdiansk, Zaporizhzhia region, \\ 71100 \\ педагогічний університет \\ Original manuscript received: October 04, 2019 \\ $\triangle$ вул. Шмідта, 4 \\ Revised manuscript accepted: December 20, 2019
}

\begin{abstract}
The article is devoted to the problem of formation of practical-oriented knowledge in physics of high school students by involvement in physical-technical modeling. The dependence of the level of students' skills to apply theoretical knowledge in physics in practical activity to the ability to simulate technical objects and technological processes is substantiated. The article defines and analyzes the functions and influence of technical creativity on the formation of knowledge of physics and their ability to apply in everyday life and future professional activity. Didactic goals of technical creativity of senior students in the formation of strong knowledge of physics and ability to apply them in various situations in life are identified and discussed. The development and use in the educational process of physics of a system of tasks with practical content gives the opportunity to partially solve the problem of developing students' interest in physical and technical knowledge, forming the skills of their application in life. Examples of the use of creative tasks of technical content, aimed at forming skills to apply knowledge of physics in everyday life, explaining natural phenomena are given. The concept of designing the structure and content of the course of physics is proposed, which is aimed at improving the methodology of formation of practical-oriented knowledge based on the physical modeling of technical objects is proposed.
\end{abstract}

Key words: physics, educational process, practice-oriented approach, modeling, high school, technical thinking.

Вступ. Сучасні тенденції розвитку науки, техніки, технологій вимагають від системи середньої освіти розробки нових підходів до якості підготовки випускників та практичної спрямованості фрізичної освіти. Вони повинні володіти не тільки теоретичними знаннями 3 природничих предметів, але й уміти застосовувати їх у повсякденному житті, поясненні природних явищ, майбутній професійній діяльності; знати й розуміти не тільки окремі фрізичні закони і явища, а й бачити 
цілісну фізичну картину світу. Фундаментальні природничо-наукові знання необхідно формувати в учнів не у вигляді певного набору законів, а 3 позицій життєвих та майбутніх професійних потреб. У системі середньої освіти фрізика як навчальний предмет стає невід'ємною складовою процесу формування розвиненої особистості.

Підготовку випускників шкіл до застосовування знань з фізики для розв'язання практичних задач можна вирішити шляхом розробки методики формування в учнів не формальних, а практико-орієнтованих інтегрованих знань. Концепція формування практико-орієнтованих знань на основі конструювання технічних моделей надає широкі можливості для підвищення ефективності практичної підготовки учнів з фізики. Разом з тим, залишаються недостатньо дослідженими проблеми конструювання змісту курсу ффізики на умовах інтеграції навчальних предметів та орієнтацією на практичну спрямованість освіти. Проблема розробки методики формування неформальних практико-орієнтованих знань та впливу фізико-технічного моделювання на якість підготовки учнів з фізики потребує подальшого вирішення.

Особливого значення у формуванні практико-орієнтованих знань учнів з фрізики набувають завданя з практичним змістом. Саме завдяки виконанню завдань з практичним змістом на основі здобутих раніше теоретичних знань формуються вміння застосовувати їх у практичній діяльності. Однак використанню такого типу завдань як засобу реалізації практико-орієнтованого навчання фізики в учнів старшої школи в наш час приділяється не достатньо уваги. У зв'язку з цим необхідна подальша розробка засобів та методів формування практико-орієнтованих знань, у тому числі й шляхом залучення учнів старшої школи до фрізико-технічного конструювання. Мета статті - можливості підвищення якості практикоорієнтованого навчання фізики шляхом впровадження в освітній процес фрізико-технічного моделювання явищ що вивчаються.

Методи та методика дослідження. Проблема підготовки учнів до застосування знань з фізики в практичній діяльності залишається однією 3 актуальних в сучасній педагогіці. 3 різних точок зору цій проблемі приділяли належну увагу у своїх працях багато вчених і методистів. Різні аспекти навчання фрізики в закладах середньої та вищої освіти досліджували українські вчені П. Атаманчук, Л. Благодаренко, В. Заболотний, О. Ляшенко, М. Мартинюк, А. Павленко, В. Сиротюк, Б. Сусь, М. Шут та інші.

Проблеми вдосконалення змісту та системи навчання фрізиці різних напрямів підготовки висвітлені d наукових працях О. Іваницького, С. Величка, О. Коновала, В. Мендерецького, І. Мороза, В. Шарко. Формування фрізико-технічних знань е процесі вивчення фрізики розглядали І. Богданов, В. Вовкотруб, А. Касперський.

Система фізичної освіти В старшій школі спрямована на формування узагальнених, цілісних знань з природничо-наукових, технічних та технологічних предметів. Кінцевою метою формування знань в учнів старших класів $€$ побудова в свідомості якісної фрізико- 
технічної моделі навколишнього середовища. Якісна модель фізичного процесу дозволить учням знайти можливості для використання набутих теоретичних знань у практичній діяльності [Шишкін, 2014]. Ця модель будується на основі наукової та фрізичної моделей світу.

Фізична картина світу заснована на вихідних філософських поняттях і категоріях, уявленнях про матерію, простір та час, рух і взаємодії, фрізичних теоріях і принципах, що виражають зв'язки між ними [Бунге, 1975], [Зикова, 2017]. Проведений ретельний аналіз співвідношень між теоріями, фрізичною та технічною картинами світу дозволив дійти висновку, що фізичні теорії $€$ найважливішими компонентами в складі фрізико-технічної моделі світу [Shyshkin, 2016]. Проте аналіз освітнього процесу з фізики в закладах середньої освіти, а також складу їх компетентностей дають можливість дійти висновку про те, що рівень фрізико-технічних знань випускників старшої школи не завжди відповідає вимогам соціального замовлення до кваліфікації випускника та його особистих потреб [Shyshkin, 2018]. Значну кількість науково-методичних та психолого-педагогічних досліджень приділено проблемі визначення поняття моделі. Ученими було розглянуто поняття моделі $з$ фрілософських позицій [Бунге, 1975]. Дослідження з визначення поняття моделі та застосування навчальних фізичних моделей у курсі фрізики було виконано І. Сліпухіною [Сліпухіна, 2012] та В. Фоменко [Фоменко, 2013]. Суттєвим недоліком сучасної шкільної освіти є пояснення без використання наукового методу пізнання фрізики, опановуючи яким, учень на уроці може і повинен пройти весь шлях від спостереження явищ і висунення гіпотези до побудови моделі й перевірки її на практиці [Зикова, 2017].

Сучасне суспільство вимагає від системи середньої освіти підготовки випускників, здатних до практичного застосування набутих теоретичних знань. Міцність і якість засвоєння знань і умінь визначається рівнем сорормованості уявлення учнів про те, як правильно та доцільно застосувати ці знання на практиці. Концепція практико-орієнтованого навчання фрізики базується на формуванні в учнів знань і вмінь вирішувати проблеми, що виникають у повсякденному житті людини, поясненні природних явищ, та формуванні готовності до застосування знань у майбутній професійній діяльності. Результати проведеного нами пілотного дослідженя свідчать про те, що понад $80 \%$ учнів старших класів не вміють використовувати теоретичні знання з фрізики в практичній діяльності [Shyshkin, 2018].

3 метою виявлення впливу навички моделювання об'єктів техніки на формування практико-орієнтованих знань з фізики серед учнів старших класів закладів середньої освіти протягом 2016-2018 навчальних років нами було проведено педагогічне дослідження за розробленими нами анкетами та тестами. Питання анкет та тестових завдань оцінені групою експертів, до складу якої ввійшли вчені та вчителі-методисти, що займаються проблемами вдосконалення методики навчання фізики. За допомогою тестів було визначено рівні практико-орієнтованих знань учнів та ефективність методики формування навичок фрізико-технічного моделювання в учнів старшої школи. Валідність анкет оцінювалась методом групової експертної оцінки 
[Черепанов, 1989]. Основні показники, які, на нашу думку, повинні бути включені до анкет, визначались пілотними дослідженнями. Рішенням робочої групи експертів було встановлено валідність анкет, що дорівнювала 0,63 . Ураховуючи те, що отримані значення валідності більше граничного $(\mathrm{B} \geq 0,63)$, ці показники використовувалися у наших науково-педагогічних дослідженнях. Відповіді на питання анкети та тестів оцінювались за 9 бальною шкалою. У деяких випадках для спрощення обробки отриманих результатів відповіді оцінювалися як низький рівень (від 1 до 3 балів), середній рівень (від 4 до 6 балів), високий рівень (від 7 до 9 балів).

Результати та дискусії. Шкільний курс фрізики передбачає формування в учнів уявлення про навколишню дійсність з позицій природничих наук у вигляді моделей. Сучасна школа має формувати знання, які випускники зможуть використовувати у майбутній професійній діяльності, розв'язанні побутових проблем, поясненні природних явищ. Визначальну роль у формуванні вмінь застосовувати знання в практичній діяльності відіграє залучення учнів до технічної творчості. Наші дослідження показали, що фрізичне моделювання технічних об'єктів та процесів сприяє активізації пізнавальної діяльності учнів на уроках фізики. Учням необхідно показати, як теоретичні знання перетворюються у практичну форму у вигляді технічних об'єктів.

Фізико-технічне моделювання неможливо формувати без розвитку технічного мислення учнів. У ньому співіснують три основних типи. До них ми відносимо: повсякденне (ненаукове), класичне (наукове) і сучасне (наукове, діалектичне за своїм характером технічне мислення). Сучасний тип технічного мислення і відповідні йому технічні знання передбачають обізнаність суб'єкта в пізнавальному процесі та його "зворотній" вплив на них; залежність отриманих результатів від інструментів, що використовуються в пізнанні.

Для дослідження рівня здібностей учнів до технічного мислення нами було розроблено тести. За допомогою тестів ми оцінювали вміння учнів читати креслення, розбиратися в схемах технічних пристроїв і їх роботі, вирішувати найпростіші фізико-технічні завдання. Тестування проводилося серед учнів старших класів закладів загальної середньої освіти. У тестах використовувались завдання у вигляді рисунків 3 можливими варіантами відповідей. Усього в дослідженні взяли участь 96 учнів закладів загальної середньої освіти. Аналіз результатів показав, що найбільший відсоток учнів мають середній рівень технічного мислення. Він становив 53\% від загальної кількості учнів VIII - XI класів. Дуже низький рівень мають $7 \%$, низький рівень-24\%, високий $-16 \%$. Якщо ж порівнювати результати тесту хлопців і дівчат, то бачимо що хлопців 3 високим рівнєм технічного мислення на $6 \%$ більше. Однак дівчат 3 середнім рівнем здібностей до технічного мислення на $8 \%$ більше.

Рівень підготовки учнів закладів середньої освіти до застосування фундаментальних знань з фрізики в практичній діяльності ми визначали методом тестування опитуванням учителів. Результати тестування щодо готовності учнів шкіл до моделювання технічних об'єктів подані на рис. 1. 
Серія: Педагогічні науки. - Вип.3. - Бердянськ : БДПУ, 2019. - 453 с.

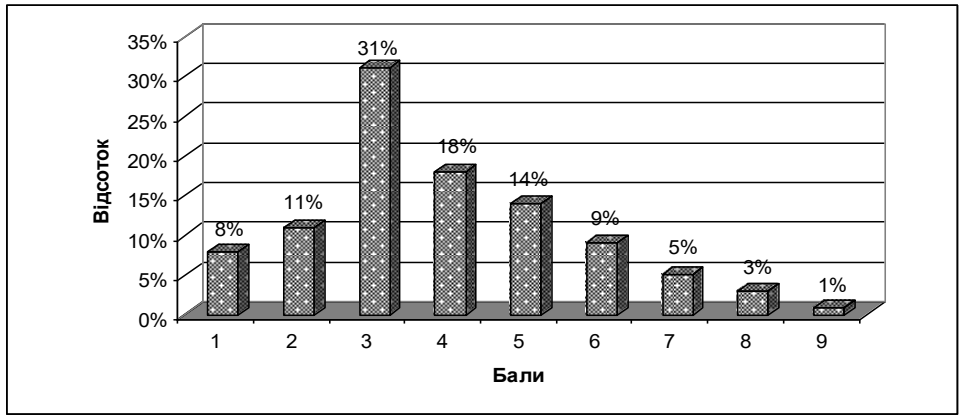

Рис. 1. Рівень готовності учнів старших класів щодо фізикотехнічного моделювання

Проведені нами дослідження показали, що $50 \%$ випускників старшої школи володіють навичками застосування знань з фізики в практичній діяльності на низькому рівні; $41 \%$ - на середньому; $9 \%$ - на високому. Аналіз результатів наших досліджень свідчить про те, що $45 \%$ вчителів визнають низький рівень залучення учнів до фрізико-технічної конструкторської діяльності, середній рівень - 50\% і високий $-5 \%$.

У формуванні практико-орієнтованих знань важливо показати учням зв'язок між теорією, фрізичною моделлю та реальним технічним об'єктом, що потрібен у житті людини. У сучасних соціальних та економічних умовах важливі не стільки енциклопедичні знання, скільки здатність застосовувати їх для вирішення конкретних проблем у реальному житті. В основу формування практико-орієнтовних знань через фрізико-технічне моделювання мають бути покладені принципи, серед яких основним $€$ принципи доцільності і практичної значущості моделі. Основною проблемою організації практико-орієнтованого навчання є підбір об'єктів для технічного моделювання відповідно до теми, що вивчається. При цьому необхідно враховувати індивідуальні особливості учнів та активізувати їх інтерес до виконання завдань. На початковому етапі фрормування навичок фрізико-технічного моделювання необхідне виконання двох умов: об'єкт моделювання має бути зрозумілим учням і привертати увагу своєю практичною значущістю; об'єкт моделювання має бути з ближнього оточення учнів.

Зв'язок об'єкта моделювання 3 повсякденним життям сприяє підвищенню інтересу та творчої активності учнів. У них виникає інтерес до отримання кінцевого результату, захоплює сам процес пошуку шляхів розв'язання поставленої задачі. Змістове наповнення завдань з фізикотехнічного моделювання вимагає їх розробці та методиці застосування на уроці й позакласній роботі учнів. Систематизувати фрізико-технічні моделі можна за змістом: політехнічним; промислово-технологічним; побутовим; природничим. Проєктування фізичних моделей з практикоорієнованим змістом передбачає виявлення та застосування фізичних закономірностей, що відбуваються на виробництві, побутових приладах, 


\section{Наукові записки БДПУ (http://bdpu.org/pedagogy/ua/)}

природних явищах. Фізико-технічні моделі 3 політехнічним та промислово-технологічним змістом містять процеси або закони, покладені в основу дії механізмів і машин сучасної техніки або технологій промислових процесів.

Практико-орієнтоване фрізичне моделювання необхідно використовувати 3 різними дидактичними цілями. Воно повинне збуджувати інтерес учнів до вивчення фрізики, розвивати розумову діяльність, формувати вміння застосовувати знання на практиці. Навчальна функція практико-орієнтованого фрізичного моделювання полягає: у конкретизації та систематизації знань учнів; формуванні системи знань про головні галузі виробництва та основні напрямки розвитку промисловості; у формуванні навичок застосування фізичних законів у повсякденному житті; у поглибленому засвоєнні фізичних закономірностей; у свідомому засвоєнні учнями програмного матеріалу; у розвитку творчих здібностей у галузі техніки; у застосуванні знань у конкретних життєвих ситуаціях; у накопиченні досвіду практичної діяльності.

Використання фрізико-технічного моделювання дозволить найбільш ефективно здійснити практико-орієнтоване навчання учнів старших класів на основі контролю за рівнем засвоєння теоретичного матеріалу і рівнем готовності до здійснення практичної діяльності. Мотиваційна функція моделювання в системі практико-орієнтованого навчання проявляється в усвідомленні учнями важливої ролі фрізичних знань і практичних умінь у житті людини. Проведені нами дослідження показали, що вміння будувати фрізичні моделі природних явищ, технічних об'єктів, технологічних процесів значно підвищують мотивацію та рівень засвоєння знань з фізики та предметів технологічної підготовки [Зикова, 2017], [Shyshkin, 2016].

Висновки. Наведена концепція конструювання структури та змісту курсу фрізики дозволяє послідовно реалізовувати всі етапи методики формування готовності випускників старшої школи в галузі технологій до застосування інтегрованих знань у практичній діяльності. Дослідження динаміки формування практико-орієнтованих знань та їх застосування в конструюванні фізичних моделей технічних об'єктів, технологічних процесів дозволяє виявляти і мобілізувати якісно нові резерви в процесі становлення майбутніх фахівців. Доведено, що проблему підвищення якості навчання фізики та формування навичок застосування знань 3 фрізики у професійній діяльності можна розв'язати шляхом фрормування в учнів вмінь конструювати фрізико-технічні моделі реальних процесів. Подальшого дослідження потребують розробка методики та методичного забезпечення формування вмінь конструювати моделі технічних об'єктів при вивченні конкретних розділів курсу фрізики в старшій школі.

\section{Література}

1.Бунге М. Философия фризики. Пер. с англ. Ю.Б. Молчанова. М.: Прогресс, 1975. 342 c.

2.Зикова К.М., Шишкін Г.О. Фізичні моделі та їх формування в системі профільного навчання. Наукові записки. Випуск 12. Серія : Проблеми методики фрізико-математичної і технологічної освіти. Частина 1. Кропивницький : РВВ ЦДПУ 
ім. В. Винниченка. 2017 С. 67-73.

3. Сліпухіна І.А. Використання моделей - аналогій як засіб формування наукового методу пізнання. Збірник наукових праць Кам'янець-Подільського національного університету імені Івана Огієнка. Серія педагогічна. 2012. №. 18. С. 28 - 31.

4.Фоменко В.В. Фундаментальні навчальні фрізичні моделі як засіб забезпечення гносеологічної єдності фрізичної освіти. Збірник наукових праць Кам'янець-Подільського національного університету імені Івана Огієнка. Серія педагогічна. 2013. №. 19. С. 191 - 193.

5.Черепанов В.С. Экспертные оценки в педагогических исследованиях / В.С. Черепанов. - М. : Педагогика, 1989. - 152 с.

6.Шишкін Г.О. Методична система формування інтегрованих знань 3 фізики в процесі підготовки вчителів технологій : [монографрія] / Г. О. Шишкін. Донецьк : Юго-Восток, 2014. - 365 с.

7.Shyshkin G.O., Kosogov I.G., Korobchenko V.Y. Physical and technical simulations in educational process of pedagogical universities / // Natural and Technical Sciences, IV(11), Issue: 96, 2016. - pp. 52-56.

8.Shyshkin G.A. Analysis of the devlopment of students' physical and technical thinking at rural schools / G.O. Shyshkin, K.M. Zykova, I.H. Kosohov // Science and Education a New Dimension. Pedagogy. And Psychology, VI(72), Issue: 174. 2018. Sept. pp. 28-30. https://doi.org/10.31174/SEND-PP2018-174VI72-06

\section{References}

1.Bunhe, M. (1975). Fylosofyia fyzyky [The philosophy of physics]. M.: Prohress [in Russian].

2.Zykova, K., Shyshkin, H. (2017) Fizychni modeli ta yikh formuvannia $v$ systemi profilnoho navchannia [Physical models and their formation in the system of profile training], Naukovi zapysky. Seriia : Problemy metodyky fizyko-matematychnoi i tekhnolohichnoi osvity. Kropyvnytskyi : RVV TsDPU im. V. Vynnychenka [in Ukrainian]. 12(1). 67-73 [in Ukrainian].

3.Slipukhina, I. (2012). Vykorystannia modelei - analohii yak zasib formuvannia naukovoho metodu piznannia [The use of models - analogies as a means of forming a scientific method of cognition], Zbirnyk naukovykh prats Kamianets-Podilskoho natsionalnoho universytetu imeni Ivana Ohiienka. Seriia pedahohichna, 18, 28-31 [in Ukrainian].

4.Fomenko, V. (2013) Fundamentalni navchalni fizychni modeli yak zasib zabezpechennia hnoseolohichnoi yednosti fizychnoi osvity [Basic educational physical models as a means of ensuring the epistemological unity of physical education], Zbirnyk naukovykh prats Kamianets-Podilskoho natsionalnoho universytetu imeni Ivana Ohiienka. Seriia pedahohichna, 19, 191-193 [in Ukrainian].

5.Cherepanov, V. (1989). Ekspertni otsinky v pedahohichnykh doslidzhenniakh [Expert assessments in pedagogical researches]. M. : Pedahohyka [in Russian].

6. Shyshkin, $\mathrm{H}$. (2014). Metodychna systema formuvannia intehrovanykh znan z fizyky $v$ protsesi pidhotovky vchyteliv tekhnolohii : monohrafiia [Methodical system of formation of integrated knowledge in physics in the process of preparation of technology teachers]. Donetsk : Yuho-Vostok [in Ukrainian.]

7.Shyshkin, G., Kosogov, I., Korobchenko, V. (2016) Physical and technical simulations in educational process of pedagogical universities, Natural and Technical Sciences, IV(11), 96, 52-56 [in English].

8.Shyshkin, G., Zykova, K., Kosohov, I. (2018) Analysis of the devlopment of students' physical and technical thinking at rural schools, Science and Education a New Dimension. Pedagogy and Psychology, VI(72), 174, 28-30 [in English]. 


\begin{abstract}
АНОТАЦІЯ
Стаття присвячена проблемі формування практико-орієнтованих знань з фрізики учнів старшої школи шляхом залучення до фрізико-технічного моделювання. Обгрунтовується залежність рівня вмінь учнів застосовувати теоретичні знання з фрізики в практичній діяльності від вмінь моделювати технічні об'єкти та технологічні процеси. У статmі визначено та проаналізовано функції та вплив технічної творчості на формування знань з фрізики $і$ вмінь їх застосовувати в повсякденному житті та майбтній професійній діяльності. Виявлено та розглянуто дидактичні иілі техніної творчості учнів старших класів у фрормуванні міцних знань з фрізики та вмінь застосовувати їх у різноманітних життєвих ситуаціях. Розробка та використання в освітньому процесі з фрізики системи завдань з практичним змістом дає можливість частково вирішити проблему розвитку інтересу учнів до фрізико-технічних знань, формування навичок їх застосування в житті. Звертається увага на необхідність використання творчих завдань технічного змісту, спрямованих на формування навичок застосовувати знання з фрізики у побуті, поясненні природних явищ. Досліджено рівень здатності учнів до технічного мислення та рівень готовності до фрізико-технічного моделювання. Пропонується концепція конструювання структури та змісту курсу фрізики, який спрямований на вдосконалення методики формування практикоорієнтовних знань на основі фрізичного моделювання технічних об'єктів.

Ключові слова: фрізика, освітній процес, практико-орієнтований підхід, моделювання, старша школа, технічне мислення.
\end{abstract}

